Развитие рынка ценных бумаг - производная от развития реального сектора. Поэтому, структура и уровень развития национальной экономики являются одним из основных факторов определяющих основные тенденции развития рынка ценных бумаг.

\section{Литература}

1. Правила выпуска, размещения и циркуляции государственных и муниципальных ценных бумаг в Азербайджанской Республике [Текст] / Государственный Комитет по Ценным Бумагам при Президенте Азербайджанской Республики, 2000.

2. Правила циркуляции фьючерсов в Азербайджанской Республике [Текст] / Государственный Комитет по Ценным Бумагам при Президенте Азербайджанской Республики, 2001.

3. Гражданский Кодекс Азербайджанской Республики [Текст] / Статья 992-1.7 и 992-1.8.

4. Правила листинга, делистинга и торговли ценными бумагами на Бакинской Фондовой Бирже [Текст] / Бакинская Фондовая Биржа.

5. Правила проведения операций РЕПО и антиРЕПО с ценными бумагами Национальным Банком Азербайджанской Республики [Текст] / Государственный
Комитет по Ценным Бумагам при Президенте Азербайджанской Республики, 2001.

6. Закон Азербайджанской Республики «О банках» [Текст] / Статья 19.1.

\section{References}

1. Pravila vypuska, razmeshhenija i cirkuljacii gosudarstvennyh i municipal'nyh cennyh bumag v Azerbajdzhanskoj Respublike (2000). Gosudarstvennyj Komitet po Cennym Bumagam pri Prezidente Azerbajdzhanskoj Respubliki.

2. Pravila cirkuljacii fjuchersov v Azerbajdzhanskoj Respublike (2001). Gosudarstvennyj Komitet po Cennym Bumagam pri Prezidente Azerbajdzhanskoj Respubliki.

3. Grazhdanskij Kodeks Azerbajdzhanskoj Respubliki. Stat'ja 992-1.7 i 992-1.8.

4. Pravila listinga, delistinga i torgovli cennymi bumagami na Bakinskoj Fondovoj Birzhe. In: Bakinskaja Fondovaja Birzha.

5. Pravila provedenija operacij REPO $i$ anti-REPO $s$ cennymi bumagami Nacional'nym Bankom Azerbajdzhanskoj Respubliki (2001). Gosudarstvennyj Komitet po Cennym Bumagam pri Prezidente Azerbajdzhanskoj Respubliki. Stat'ja 19.1

6. Zakon Azerbajdzhanskoj Respubliki «O bankah».

Рекомендовано до публікаиії д-р екон. наук, професор профессор Гасанов Р. Т. Дата надходження рукопису 23.01.2015

Абдинов Рамиз Мобил оглы, кандидат экономических наук, доцент, кафедра «Экономика и менеджмент», Азербайджанская Государственная Нефтяная Академия, ул. Кадырли, 75, г. Баку, Азейрбаджан, AZ106

Тагизаде Севиндж Сакит кызы, диссертант, Азербайджанская Государственная Нефтяная Академия, ул. Кадырли, 75, г. Баку, Азейрбаджан, AZ106

E-mail: qezale@mail.ru

УДК 332.334.4.: 631.618

DOI: $10.15587 / 2313-8416.2015 .37803$

\title{
ДЕЯКІ МЕТОДОЛОГІЧНІ АСПЕКТИ ЕКОЛОГО-ЕКОНОМІЧНОЇ ОЦІНКИ РЕКУЛЬТИВАЦІЇ ПОРУШЕНИХ ЗЕМЕЛЬ
}

\section{(C). І. Галаган}

Доведено, щзо ціна землі, яка вилучається із сільськогосподарського виробництва для видобутку корисних копалин складається з ціни значущості землі як компонента природи, з ціни землі як основного засобу виробництва, з ціни на відновлення колишньої родючості та з ціни на поліпшення екологічного стану довкілля. На основі агротехнічних характеристик гірських порід показані галузі економіки їх подальшого використання

Ключові слова: техногенний ландшафт, рекультивація порушених земель, иіна землі, витрати, чистий дохід

It is proved that the price of land that is taken out of agricultural production for mining operations consists of the price of the importance of land as a component of nature, the price of the land as the main means of production, price to restore fertility and price of improvement of the ecological status of environment. Based on the agronomic characteristics of rocks there are shown the industries of their further use

Keywords: technogenic landscape, recultivation of disturbed lands, land price, costs, net income

\section{1. Вступ}

Наразі під впливом виробничої діяльності людини відбуваються грандіозні зміни як живої, так і неживої природи. Особливо під час видобутку мінеральної сировини, що призводить до руйнації динамічної рівноваги в природних екосистемах та до погіршення екологічного стану навколишнього середовища.

Реалії сьогодення свідчать про те, що техногенний прес на довкілля зростає 3 кожним роком і одним з його головних наслідків $є$ створення несприятливих для людини санітарно-гігієнічних 
умови, особливо після видобутку корисних копалин кар'єрним способом.

В Україні такі техногенні ландшафти вже складають 150 тис. гектарів і все далі поширюються на сільськогосподарські угіддя. Руйнуються високородючі чорноземи, цінність яких залежить від природно-економічних умов конкретної місцевості. Такі умови в регіонах є різними. Отже і цінність грунтів $є$ різною. Через це гірничорудні підприємства завдають і різної шкоди місцевому населенню. Аби позбутися цієї шкодочинності гірничодобувної промисловості, порушені землі треба обов'язково рекультивовувати, тобто відновлювати їхню колишню цінність.

\section{2. Постановка проблеми}

Наразі рекультивація (відновлення) порушених земель ускладнюється відсутністю єдиної методики оцінки збитків суспільству від руйнації грунтового покриву і створення техногенних ландшафтів. Частково це пояснюється тим, що раніше економісти не в повній мірі оцінювали роль природних ресурсів в економіці і наслідки після їх видобутку.

Зрозуміло, що для одержання порівнянних даних про грунти у різних природно-економічних зонах України, треба мати єдину методику економічної оцінки земель. Саме це дозволить визначити збиток, який наноситься суспільству під час видобутку копалин і обгрунтовано планувати рекультиваційні роботи після їх завершення.

\section{3. Літературний огляд}

Заради об'єктивності треба зазначити, що проблема оцінки землі $\epsilon$ однією 3 самих суперечливих методологічних питань. Щодо рекультивованих земель ця проблема $є$ ще більш складною і знаходиться лише на початку свого рішення.

Наразі $\epsilon$ наукові розробки щодо теорії i практики оціночно-кадастрових робіт [1-7], але i дотепер залишаються дискусійними, навіть не вирішеними, деякі важливі питання методології економічної оцінки земель. На жаль, про таку важливу категорію як оцінка відновлених земель 3 точки зору їхньої еколого-економічної значущості для суспільства взагалі поки що навіть мови немає. Тому високої актуальності набуває вирішення цих питань, особливо в умовах формування ринкових відносин у сільському господарстві та ще й на фоні поступового зменшення кількості орних земель.

\section{4. Оцінка порушених земель та можливі напрямки їх подальшого використання}

На наш погляд, для дбайливого використання земель, відчужених під видобуток корисних копалин, і повернення їх у належному стані для подальшого використання у сільському господарстві, треба обов'язково враховувати вартість землі до порушення і після іiї рекультивації.

При відводі земель для видобутку мінеральної сировини гірничорудні підприємства повинні виплачувати компенсаційні суми за отримання певної площі угідь. Такі витрати на компенсацію $\left(\mathrm{B}_{\kappa}\right)$ за відчуження земель можна визначити за формулою

$$
\mathrm{B}_{\mathrm{K}}=\mathrm{S}_{\mathrm{o}} \cdot \mathrm{B}_{\mathrm{o}}, \text { грн., }
$$

де $\mathrm{S}_{\mathrm{o}}$ - площа, яка буде порушена і зайнята відвалами кар'єрів, га; В - витрати на компенсацію 1 га відчужених земель, грн.

Сума компенсації за землю залежить від якості проведення гірничотехнічної рекультивації. Основною іiі метою має бути збереження сільськогосподарського потенціалу відновлених грунтів. Якщо гірничорудне підприємство провело рекультиваційні роботи якісно, що надає можливість отримати валовий збір колишньої продукції, сума компенсації за землю повертається цьому гірничому підприємству або враховується при наступному відчуженні землі. Якщо рекультивовані землі не спроможні забезпечити колишню валову сільськогосподарську продукцію, то сума компен-сації за землю повертається частково, обов'язково в прямій залежності від якості проведеної рекуль-тивації і, особливо, від вмісту гумусу в орному шарі. Наприклад, до руйнації вміст гумусу у грунті складав 4,0 \%. Після рекультивації у насипному шарі вміст гумусу складає 2,0\%. Отже компенсаційні витрати повертаються тільки на половину.

При такому підході гірничорудні підприємства будуть зацікавленні у збереженні і раціональному використанні маси родючого чорнозему та якісному виконанні рекультиваційних робіт.

На наш погляд, саме це сприятиме відтворенню рівня родючості рекультивованих земель і поліпшенню санітарно-гігієнічних умов довкілля. В цьому випадку витрати на рекультивацію відвалів $\left(\mathrm{B}_{\text {р.в }}\right)$ тобто на проведення меліоративних (культуртехнічних та хімічних) заходів в орному шарі ми пропонуємо визначати 3 допомогою наступної формули:

$$
\mathrm{B}_{\text {p.в. }}=\mathrm{S}_{\mathrm{o}} \cdot \mathrm{B}_{\mathrm{p}}, \text { грн., }
$$

де $\mathrm{B}_{\mathrm{p}}$ - витрати на рекультивацію 1 га відвальної площі, грн.

Зрозуміло, що у зв'язку із відчуженням земель сільськогосподарське підприємство втрачає чистий дохід, який могло б отримати 3 цієї площі. Тим більше, що дохід від вилученої землі надходив би багато разів. Його сума, якою б малою вона не була за один рік, у результаті додавання може бути скільки завгодно великою. Отже, при відведенні земельних ділянок гірничорудним підприємствам в короткострокове або довгострокове користування сільське господарство втрачає чистий дохід, який могли б дати ці землі. Такі втрати чистого доходу $\left(\mathrm{B}_{\text {чд }}\right)$ можна розрахувати за формулою:

$$
\mathrm{B}_{\text {чд }}=\mathrm{S}_{\mathrm{o}} \cdot \mathrm{ЧД} \cdot \mathrm{T} \cdot \mathrm{K}_{\mathrm{iнт}}, \text {, грн., }
$$

де ЧД - чистий дохід 31 га сільськогосподарських угідь до їхнього порушення, грн., Т - термін роботи кар'єру до відновлення порушеної землі, роки, $\mathrm{K}_{\text {інт.- }}$ коефіцієнт інтенсифікації сільськогосподарського виробництва за період, що оцінюється $(1,5)$.

Однак, величина чистого доходу не може в повній мірі характеризувати цінність ре культивованої землі. Один і той же чистий дохід може бути 
одержаним на різних за якісними показниками землях при різних витратах виробництва. Окрім того, вважати всю величину чистого доходу від ображенням природних умов теж не можна.

Оскільки природна родючість невід'ємна від економічної родючості, то більш родючою повинна вважатися та рекультивована земля, яка забезпечує високу окупність витрат, тобто яка забезпечує більш високий дохід на одиницю витрат. Виходячи 3 цього, таким показником може вважатися розмір чистого доходу на 1 грн. витрат.

В цьому випадку повний збиток від відчуження земель (3б.) із сільськогосподарського використання можна розрахувати за наступною формулою:

$$
3_{\sigma .}=\mathrm{B}_{\kappa}+\mathrm{B}_{\text {р.в. }}+\mathrm{B}_{\text {чд, }}, \text { грн. }
$$

На наш погляд, при вилучені землі для видобутку корисних копалин потрібно обов'язково мати на увазі і те, що крім збитку, одержуваного сільськогосподарським підприємством безносередньо від вилучення земельних угідь, а також витрат на компенсацію вартості будівель і споруд, які $\epsilon$ на ділянці (або витрат на їх перенесення i відновлення на новому місці), вартості не використаних витрат, раніше вкладених у ділянку (меліоративні роботи, внесення добрив, проведення землеустрою тощо). Треба також враховувати збитки, які зумовлені побічними діями (наприклад, зниження продуктивності сільськогосподарських культур на навколишніх масивах староорних земель в результаті забруднення посівів пилом, або відкачки води 3 кар'єру і зниження, таким чином, рівня грунтових вод, що призводить до опустелювання місцевості).

Наразі з'ясувати всі витрати на рекультивацію порушених земель складно тому, що витрати підприємств (гірничорудних і сільськогосподарських) $є$ приватною таємницею і для ознайомлення 3 нею треба мати певний хист. Це ускладнюється і тим, що останнім часом майже не публікуються дані про витрати на різні види робіт i взагалі про витрати на поліпшення екологічного стану порушеної місцевості. Саме через це ми вважаємо, що при визначенні ефекту від рекультивації у виді поліпшення ландшафтної території треба використовувати загальну екологоекономічну оцінку, а у виді окремих угідь конкретного цільового використання - приватну оцінку, але теж $з$ дотриманням екологічних вимог.

Реальні показники свідчать про те, що витрати на рекультивацію одного гектару землі коливаються у значному інтервалі. Цілком природно, що в різних галузях господарства різний ступінь корінного порушення земель, а звідси - різний обсяг гірничотехнічних робіт і величина витрат в розрахунку на одиницю площі. Отже величина витрат на рекультивацію одного гектару земель багато в чому залежить від напрямку наступного їхнього використання.

Як показала практика, рекультивовані землі степового Придніпров'я можна використовувати в багатьох галузях економіки (табл. 1).

Задля цього треба, ще до проведення гірничотехнічного етапу рекультивації, здійснити фізико-хімічну експертизу гірських порід і на основі цієї експертизи прогнозувати майбутній напрямок їхнього використання.

Зрозуміло, що перевагу треба надавати сільськогосподарському напрямку, як найбільш важливому для населення. Цей напрямок надає людям матеріальні блага і робочі міста.

Якщо відпрацьовані ділянки складені скельними грунтами або містять недопустиму для рослин кількість шкідливих речовин, вони мають бути відведеними під лісопаркові масиви або заповідні зони, але після проведення відповідних меліоративних заходів.

При всьому при цьому, вибір оптимального напрямку подальшого використання порушених земель повинно передбачати досягнення економічно доцільного та екологічно безпечного рівня віддачі 3 одиниці площі цих земель, запровадження енергоощадних та екологічно безпечних технологій обробітку грунту та вирощування сільськогосподарських культур.

Таблиця 1

Галузі економіки для подальшого використання гірських порід залежно від їх природних властивостей

\begin{tabular}{|c|c|c|}
\hline $\begin{array}{c}\text { Галузь } \\
\text { економіки }\end{array}$ & Напрям використання & $\begin{array}{c}\text { Агротехнічна } \\
\text { характеристика гірських порід }\end{array}$ \\
\hline \multirow[t]{3}{*}{$\begin{array}{c}\text { Сільсько- } \\
\text { господарська }\end{array}$} & Рілля & $\begin{array}{c}\text { Четвертинні і третинні відкладення без шкідливих домішок, які } \\
\text { покриті родючим шаром маси чорнозему завтовшки не менше } 40 \text { см. }\end{array}$ \\
\hline & $\begin{array}{l}\text { Косовиці з розвиненим } \\
\text { бджільництвом. }\end{array}$ & $\begin{array}{c}\text { Сплановані та частково сплановані четвертинні і третинні } \\
\text { відкладення без шкідливих домішок. }\end{array}$ \\
\hline & $\begin{array}{c}\text { Плодово-ягідні } \\
\text { насадження }\end{array}$ & $\begin{array}{c}\text { Частково сплановані четвертинні і третинні відкладення без } \\
\text { шкідливих домішок з використанням терас, відкосів відвалів із } \\
\text { складним рельєфом і з внесенням маси чорнозему у посадкові } \\
\text { ями, борозни, канави } \\
\end{array}$ \\
\hline \multirow[t]{2}{*}{$\begin{array}{c}\text { Лiсо- } \\
\text { господарська }\end{array}$} & $\begin{array}{c}\text { Промислове } \\
\text { лісорозведення, } \\
\text { лісопаркове озеленення }\end{array}$ & $\begin{array}{c}\text { Частково сплановані четвертинні і третинні відкладення без } \\
\text { шкідливих домішок. } \\
\text { Скельні відвали та тераси. }\end{array}$ \\
\hline & $\begin{array}{l}\text { Меліоративне залісення, } \\
\text { заповідні зони. }\end{array}$ & $\begin{array}{c}\text { Четвертинні і третинні малородючі відкладення, а також скельні } \\
\text { відвали сплановані та частково сплановані. }\end{array}$ \\
\hline $\begin{array}{l}\text { Водо-рибо- } \\
\text { господарська }\end{array}$ & $\begin{array}{c}\text { Ставкове } \\
\text { рибогосподарство }\end{array}$ & $\begin{array}{c}\text { Водонепропускне дно відпрацьованого простору кар’єрів, які } \\
\text { заповнені біологічно якісними водами із потрібним водообміном. }\end{array}$ \\
\hline
\end{tabular}


Ми вважаємо, що вибір оптимального напрямку рекультивації порушених земель є проблемою, яка повинна вирішуватися на основі врахування вимог цілого комплексу політичних, соціальних, екологічних і економічних факторів.

Найголовнішими 3 них $\epsilon$ :

a) грунтово-кліматичні особливості місцевості і спеціалізація сільськогосподарських підприємств до руйнації грунтів; земель;

б) фізико-хімічні властивості відновлених

в) витрати на рекультивацію;

г) можливі прибутки від подальшого використання рекультивованих земель;

д) вплив впровадженого напрямку на поліпшення екологічного стану довкілля.

Таке різноманіття еколого-економічних факторів відіграє різнозначну роль при визначенні не тільки шляхів і способів рекультивації, але i їx направленості для подальшого використання.

\section{5. Апробація результатів дослідження}

За темою даної роботи опубліковано понад 50 статей у вітчизняних та закордонних видавництвах.

Вони демонструвалися і доповідалися на VIII та IX з'їздах Українського Товариства Грунтознавців та Агрохіміків (м. Житомир, 2010 р., м. Миколаїв, 2014 р.), на Міжнародному симпозіумі (м. Дніпродзержинськ, 2010 р.), на Міжнародних і вітчизняних науково-практичних конференціях і семінарах: (м. Павлоград. - 2007 р.; м. КамянецьПодільський, 2007 р.; м. Львів, 2008 р.; м. Донецьк, 2008 р.; м. Воронеж, 2009 р.; м. Донецьк, 2010 р; м. Дніпропетровськ, 2011 р.; м. Воронеж, 2012 р.; м. Дніпропетровськ, 2012 р.; м. Новосибирск, 2013 р.; м. Дніпропетровськ, 2013 р; м. Донецьк, 2014 р.; м. Херсон, 2014 р.), а також на щорічних наукових конференціях професорсько-викладацького та аспірантського складу Дніпропетровського державного аграрно-економічного університету, на засіданнях кафедри економічної теорії і економіки сільського господарства та на засіданнях кафедри загального землеробства та грунтознавства.

\section{6. Висновки}

У статті на основі проведених досліджень розв'язано наукову проблему - розроблення теоретичних i методологічних положень щодо оцінки земель, які відводяться під гірничі розробки та їх подальшого використання після рекультивації. Це дало підстави для наступних висновків:

1. В Україні видобуток корисних копалин відкритим способом супроводжується руйнацією грунтів та створенням техногенних ландшафтів рекуль-тивація яких потребує значних додаткових витрат.

2. Рекультивовані землі - це створений ресурс багатофункціонального значення. Вони є складовою базису сільськогосподарського виробництва i визначаються еколого-економічними функціями, що формують їхню виробничу цінність. Одночасно вони $€$ оригінальним продуктом і предметом праці, що робить їх теоретичним і практичним фундаментом для подальшого використання у певній галузі економіки.

3. Еколого-економічна ефективність використання рекультивованих земель визначається натуральними, вартісними та економічними показниками. Зокрема, розміром компенсаційних витрат за відчуження земель, втрат сільськогоспо-дарським підприємством чистого доходу, яке воно могло б отримати 3 цієї площі, витратами на прове-дення меліоративних заходів в орному шарі і т. д.

4. Вибір оптимального напрямку рекультивації порушених земель $є$ проблемою, яка повинна вирішуватися на основі врахування цілого комплексу політичних, соціальних, екологічних і економічних факторів. Їх різноманіття відіграє різнозначну роль при визначенні не тільки шляхів i способів рекультивації, але і їх направленості для подальшого використання на благо людям.

\section{Література}

1. Олейник, В. Я. Методологические вопросы оценки эффективности рекультивации земель [Текст] / В. Я. Олейник // Эколого-биологические и социальноэкономические основы сельскохозяйственной рекультивации в степной черноземной зоне УССР. - 1984. - Т. 49. C. $155-164$.

2. Горлов, В. Д. Рекультивация земель на карьерах [Текст] / В. Д. Горлов. - М.: Недра, 1981. -260 с.

3. Барановська, О. Д. Удосконалення методів економічної оцінки землі в умовах ринкових відносин (на прикладі господарств Лісостепу України) [Текст]: автореф. ... дис. канд. екон. наук / О. Д. Барановська. Дніпропетровськ, 1997. - 25 с.

4. Борисова, В. А. Економічні основи природокористування в АПК [Текст] / В. А. Борисова. - Суми: „Довкілля", 2004. - 356 с.

5. Мельник, Л. Ю. Наукові основи ринку земель [Текст] / Л. Ю Мельник, П. М. Макаренко // Економіка АПК. - 2012. - № 9. - С. 10-15.

6. Макаренко, П. М. Моделі аграрної економіки [Текст] / П. М. Макаренко. - К.: ННЦІАЕ, 2005. - 682 с.

7. Мармуль, Л. О. Регіональне управління та регулювання використання земельних ресурсів [Текст]: монографія / Л. О. Мармуль, В. А. Романова. - К.: ННЦ IAE, 2007. - $192 \mathrm{c}$.

\section{References}

1. Oleinik, V. I. (1984). Methodological issues evaluate the effectiveness rekultivace landю Ecological-biological and socio-economic basis for cooperative rekultivace in the steppe Chernozem zone of the USSR, 49, 155-164.

2. Gorlov, D. C. (1981). Reclamation of land for quarries. Moscow: Nedra, 260.

3. Baranovskaya, O. D. (1997). Improvement of methods for the economic valuation of land in the conditions of market relations (for example, the farms of Ukrainian forestSteppe). Dnepropetrovsk, 25.

4. Borisova, V. A. (2004). The Economic Foundation of natural resources in APC. Sumy: «Dovcilliy», 356.

5. Melnic, L. J., Makarenko, P. M. (2012). Scientific basis of the land market. Economics of agriculture, 9, 10-15.

6. Makarenko, P. M. (2005). Models of agricultural Economics. Kiev: NICE, 682.

7. Marmul, L. O., Romanova, V. A. (2007). Regional management and regulation of land use. Kiev: NSC IAE, 192. 
Галаган Тетяна Іванівна, кандидат економічних наук, доцент, кафедра економічної теорії та економіки сільського господарства Дніпропетровський державний аграрно-економічний університет, вул. Ворошилова, 25, м. Дніпропетровськ, Україна, 49600

E-mail: Uzbek_ivan@mail.ru

\author{
УДК 336.717. 18:339.17
}

DOI: $10.15587 / 2313-8416.2015 .37937$

\title{
СИСТЕМА ПОКАЗНИКІВ ГРОШОВИХ ПОТОКІВ ДЛЯ ОЦІНКИ ЕФЕКТИВНОСТІ ДІЯЛЬНОСТІ ТОРГОВЕЛЬНИХ ПІДПРИЕМСТВ
}

\author{
(C) А. П. Грінько, П. Л. Гринько
}

Ми розглянули переваги та недоліки використання показників оцінки ефективності діяльності торговельних підприємств, визначили роль показників грошових потоків системі економічного управління, представили формули їх розрахунків та розкрили аналітичні значення для використання в практичній діяльності

Ключові слова: грошові потоки, показники, прибуток, коефіцієнти, торговельні підприсмства,економічне управління, аналіз

We have considered the advantages and disadvantages of using indicators to evaluate the effectiveness of trading enterprises, determined the cash flow performance in the economic management, also we have presented formulas for their calculation and developed an analytical value for practical using

Keywords: cash flows, indicators, profit, coefficients, trading enterprises, economic management, analysis

\section{1. Вступ}

В умовах ринкової економіки діяльність українських підприємств виявилась пов'язаною з їх попаданням в зону господарчої невизначеності i підвищеного ризику. Отримавши право самостійного виходу на міжнародний i внутрішній ринки, більшість підприємств встала перед проблемою оцінки фінансового стану и платіжної надійності свого підприємства і потенційних партнерів. Традиційно визначені показники прибутку не дають адекватної оцінки діяльності підприємства. Тому представляється за доцільне оцінювати ефективність діяльності підприємства за допомогою системи показників грошових потоків, а не акцентувати увагу тільки на показниках прибутку.

\section{2. Постановка проблеми}

У сучасних умовах бізнес-середовища фінансова звітність $\epsilon$ найважливішим елементом для прийняття зважених управлінських рішень, розробки фінансової стратегії і політики за основними аспектами діяльності при виявленні конкурентних переваг. Інформація Звіту про грошові кошти дуже корисна для створення моделі оцінки і дисконтування грошових потоків на довгострокову перспективу і збільшує порівняність звітних даних, оскільки цей звіт усуває вплив застосування різних облікових методів для однакових подій і операцій, забезпечує розуміння фінансової структури підприємства. Остання обставина робить даний звіт найбільш придатним при порівняльних оцінках фінансового стану різних підприємств. Але для більшості українських організацій аналіз і планування чистого прибутку давно стали стандартною практи- кою оцінки ефективності роботи підприємства, решта показників, зокрема грошові потоки, використовується далеко не на всіх підприємствах, що впливає на адекватність оцінки ефективності діяльності та правильність управлінських рішень.

\section{3. Літературний огляд}

Питанням управління грошовими потоками присвячено велику низку праць вітчизняних та зарубіжних учених: І. Бланка [1], В. Бочарова [2], Н. Власової [3], В. Ковальова [4], Л. Лігоненко [5], Т. Хлевицької, Хервіга Р. Фріда [6], К. Уорда [7], В. Шмідта та інших. Але в існуючих розробках зарубіжних i вітчизняних учених досліджуються загальнотеоретичні проблеми управління грошовими потоками. Разом із тим, аналіз результатів дослідження свідчить про недостатню розробленість наукових рекомендацій та практичних методик $з$ управління грошовими потоками в торговельних підприємствах. Тому $є$ доцільним дослідити можливість використання системи показників грошових потоків для оцінки ефективності роботи торговельного підприємства в умовах ринкової економіки.

4. Методика оцінки ефективності діяльності підприємства за допомогою системи показників грошових потоків

Фінансова звітність є основою для аналізу структури та обсягу грошових потоків та їх видів i дозволяє оцінити здатність підприємства генерувати грошові потоки в майбутньому, що $є$ індикатором його успішності. Враховуючи велику різноманітність джерел інформації для проведення аналізу грошових потоків, виникає необхідність їх систематизації та 